\title{
Detection of IgE Insulin Antibody with Radioallergosorbent Test
}

\author{
S. Nakagawa ${ }^{1}$, N. Saito ${ }^{2}$, H. Nakayama ${ }^{1}$, T. Sasaki ${ }^{1}$, T. Watanabe ${ }^{1}$, and S. Aoki ${ }^{1}$ \\ ${ }^{1}$ The Second Department of Medicine, Hokkaido Universitiy School of Medicine, and ${ }^{2}$ Department of Medicine, \\ Sapporo Railway Hospital, Sapporo, Japan
}

\begin{abstract}
Summary. An in vitro method for detecting $\operatorname{IgE}$ insulin antibody using the principle of the radioallergosorbent test (RAST) is described. In six patients with insulin allergy, the RAST values were higher than in normal persons or insulin-treated diabetics without insulin-allergy. No differences were observed between normal persons and insulin-treated diabetics without insulin-allergy. Moreover, it was observed that in one patient treated with highlypurified insulin, there was a gradual decrease of RAST value parallel to the radioinsulin binding activity and clinical allergic symptoms. The RAST value of insulin is slightly inhibited by non- $\operatorname{IgE}$ antibodies and is, therefore, a semiquantitative value. However, the RAST is simple to perform and reproducible; It therefore is very useful in the detection of $\mathrm{IgE}$ insulin antibodies.
\end{abstract}

Key words: $\operatorname{IgE}$ insulin antibody, insulin allergy, radioallergosorbent test, highly purified insulin, IgE, monocomponent insulin.

The "immediate type" of insulin allergy presents an obstacle to insulin therapy. The antibody causing this type of allergy was confirmed to be IgE class by Patterson et al. [1] in 1969. In the patient's serum there is only a low concentration of $\operatorname{IgE}$ antibodies in the presence of a high concentration of IgG antibodies; for this reason detection of the insulin specific IgE antibodies by direct binding of radioinsulin to the patient's serum is impracticable.

As a biological method for detecting reagenic antibodies, the passive cutaneous reaction on another person's skin (Prausnitz-Küstner Test) has been used, but this procedure can cause serum hepatitis or other dangerous infections in the recipient.

In the in vitro test, Patterson et al [2] used radioimmunodiffusion (RID) and polystyrene tube immunoadsorbent assay (PTIA) to detect IgE insulin antibodies, but this RID method is time-consuming and insensitive to IgE antibodies and the preparations of high concentration of $\operatorname{IgE}$ and anti-IgE globulin solutions required for the PTIA is not feasible in many situations. It is therefore undesirable for routine use.

In 1967, Wide et al. [3] reported a method for detecting $\operatorname{IgE}$ antibody against pollen antigens with cellulose-coupled antigen and radioactive anti- $\operatorname{IgE}$ globulin (Radioallergosorbent Test, RAST).

This report describes a method for detecting IgE insulin antibody in serum by using the principle of the RAST and the application of this method for the diagnosis of insulin allergy.

\section{Patients and Methods}

\section{Patients}

The patients allergic to insulin used in this study were six diabetics who showed generalized or severe local dermal reactions within an hour after injection of insulin preparation. The type of the reactions and specifity of antigen were confirmed by skin tests with purified insulins from several sources.

As control, five diabetic patients treated with insulin without the reactions and five normal volunteers were used.

The clinical details of the patients and the volunteers are described in Table 1.

Test solutions for the skin test were prepared by dissolving the same purified insulins as those used 
Table 1. Details of patients and control subjects

\begin{tabular}{|c|c|c|c|c|c|c|}
\hline \multicolumn{7}{|l|}{ Allergic patients } \\
\hline & Case 1 & Case 2 & Case 3 & Case 4 & Case 5 & Case 6 \\
\hline Age (years) & 35 & 44 & 58 & 52 & 51 & 52 \\
\hline Sex & $\mathrm{M}$ & M & M & $\mathrm{F}$ & $\mathrm{F}$ & M \\
\hline $\begin{array}{l}\text { Duration of D.M. } \\
\text { (years) }\end{array}$ & & & 13 & 4 & 6 & 4 \\
\hline Type of D.M. & adult & $\begin{array}{l}10 \\
\text { adult }\end{array}$ & adult & adult & adult & $\begin{array}{l}4 \\
\text { adult }\end{array}$ \\
\hline $\begin{array}{l}\% \text { of ideal body } \\
\text { weight }\end{array}$ & & & & & & \\
\hline $\begin{array}{l}\text { weight } \\
\text { Other drug used }\end{array}$ & $\begin{array}{l}101 \\
\text { no }\end{array}$ & $\begin{array}{l}113 \\
\text { no }\end{array}$ & $\begin{array}{l}98 \\
\text { no }\end{array}$ & $\begin{array}{l}113 \\
\text { no }\end{array}$ & 111 & $\begin{array}{l}90 \\
\text { no }\end{array}$ \\
\hline Previous insulin & Lente (Novo) & Lente (Novo) & Lente (Novo) & no & Lente (Novo) & Lente (Novo) \\
\hline therapy $^{\mathrm{a}}$ & $6 \mathrm{~m}(2 \mathrm{y})$ & $\begin{array}{l}50 \mathrm{~d}(9 \mathrm{y}) \\
1 \mathrm{~m}(5 \mathrm{y}) \\
2 \mathrm{~m}(2 \mathrm{y})\end{array}$ & $20 \mathrm{~d}(10 \mathrm{y})$ & & $2 \mathrm{~m}(2.5 \mathrm{y})$ & $5 \mathrm{~m}(4 \mathrm{y})$ \\
\hline Allergy against & Lente (Novo) & Rapitard (Novo) & $\begin{array}{l}\text { Rapitard } \\
\text { (Novo) }\end{array}$ & $\begin{array}{l}\text { Regular } \\
\text { (Shimizu) }\end{array}$ & $\begin{array}{l}\text { Regular } \\
\text { (Shimizu) }\end{array}$ & Lente (Novo) \\
\hline Insulin dose $(\mathrm{U} / \mathrm{d})$ & 56 & 12 & 28 & 20 & 36 & 56 \\
\hline $\begin{array}{l}\text { Insulin treatment } \\
\text { before allergy }\end{array}$ & $12 \mathrm{~d}$ & $3 d$ & $14 d$ & $15 \mathrm{~d}$ & $3 d$ & $1 \mathrm{~m}$ \\
\hline \multicolumn{7}{|c|}{ Insulin-treated non-allergic patients } \\
\hline & Case 7 & Case 8 & Case 9 & Case 10 & Case 11 & \\
\hline Age (years) & 66 & 59 & 54 & 58 & 55 & \\
\hline Sex & M & $\mathrm{F}$ & $\mathrm{F}$ & F & $\mathrm{F}$ & \\
\hline $\begin{array}{l}\text { Duration of D.M. } \\
\text { (years) }\end{array}$ & 18 & 19 & 7 & 4 & 7 & \\
\hline $\begin{array}{l}\text { Type of D.M. } \\
\% \text { of ideal body }\end{array}$ & adult & adult & adult & adult & adult & \\
\hline $\begin{array}{l}\text { weight } \\
\text { Previous insulin }\end{array}$ & 88 & 110 & 81 & 92 & 100 & \\
\hline $\begin{array}{l}\text { therapy } \\
\text { Duration of insulin }\end{array}$ & no & no & no & no & no & \\
\hline therapy (years) & 4 & 11 & 1.8 & 4 & 7 & \\
\hline Insulin dose $(\mathrm{U} / \mathrm{d})$ & $\begin{array}{l}\text { Lente } 40 \\
\text { (Novo) }\end{array}$ & $\begin{array}{l}\text { Rapitard } 20 \\
\text { (Novo) }\end{array}$ & $\begin{array}{l}\text { Lente } 20 \\
\text { (Novo) }\end{array}$ & $\begin{array}{l}\text { Lente } 20 \\
\text { (Novo) }\end{array}$ & $\begin{array}{l}\text { Lente } 20 \\
\text { (Novo) }\end{array}$ & \\
\hline \multicolumn{7}{|l|}{ Normal subjects } \\
\hline & Case 12 & Case 13 & Case 14 & Case 15 & Case 16 & \\
\hline Age (years) & 52 & 47 & 44 & 66 & 41 & \\
\hline Sex & $F$ & $F$ & $\mathrm{M}$ & $\mathrm{F}$ & M & \\
\hline G.T.T. & normal & normal & normal & normal & normal & \\
\hline Diseases & no & no & no & no & no & \\
\hline
\end{tabular}

a Numbers out of parentheses show duration of previous treatment and numbers in parentheses show interval between previous treatment and present treatment

for the preparation of RAST discs in $9 \mathrm{~g} / \mathrm{l} \mathrm{NaCl}$ solution in the concentration of $0.06 \mathrm{U} / \mathrm{ml}$. After filtering through sterilized Milipore filters, $0.05 \mathrm{ml}$ of these insulin solutions were injected intradermally in the antecubital region. The extent of skin inflammation in the skin test was graded from 0 to 3.0 indicates a non-specific inflammation (induration $<4 \mathrm{~mm}$ and/or erythema $<10 \mathrm{~mm}$ in diameter), 1 indicates slight inflammation (induration; $5-8 \mathrm{~mm}$ and/or erythema: $11-19 \mathrm{~mm}$ ), 2 indicates moderate inflammation (induration: 9-14 $\mathrm{mm}$ and/or erythema: $20-39 \mathrm{~mm}$ ), and 3 indicates severe inflammation (induration: > $15 \mathrm{~mm}$ and/or erythema
$>40 \mathrm{~mm}$ ). The results of the skin tests are described in Table 2.

\section{RAST}

Filter paper discs $(6 \mathrm{~mm}$ in diameter, Toyo Roshi Co., Tokyo, Japan) activated by a CNBr method [4] were coupled to insulin according to the method described below. The insulins used were purified bovine insulin (10 times recrystallized, Novo Research Institute, Copenhagen, Denmark), purified porcine insulin (10 times recrystallized, Novo), highly purified porcine insulin (Monocomponent insulin, 
Table 2. Results of skin tests

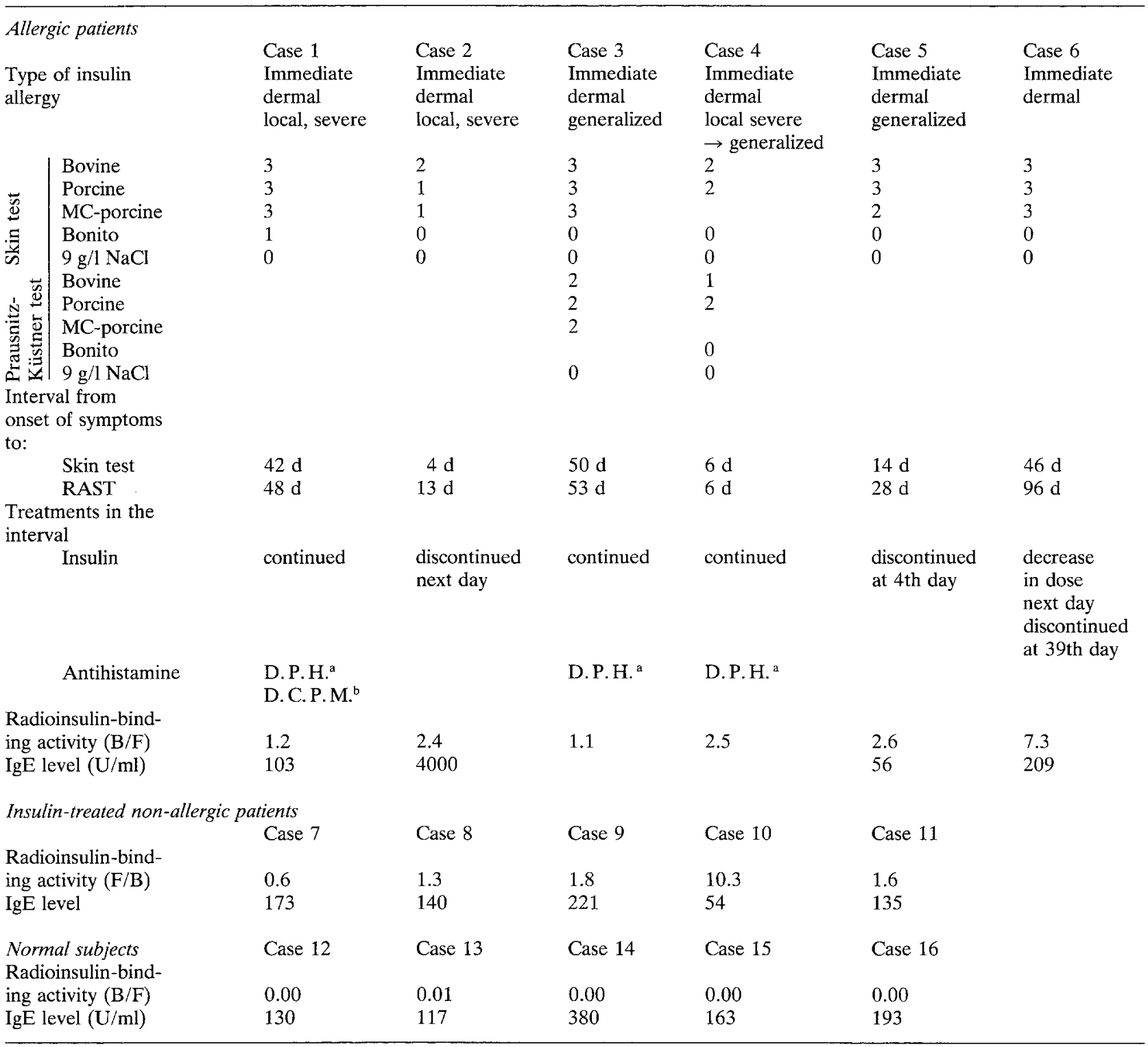

D.P.H.: Diphenhydramine $12 \mathrm{mg} / \mathrm{d}$, p.o.

b D.C.P.M.: Dextro-chlorpheniramine maleate $30 \mathrm{mg} / \mathrm{d}$, s.c.

Novo) or bonito insulin (Shimizu Pharmaceutical Co., Shimizu, Japan).

One hundred activated paper discs were immersed in $10 \mathrm{ml}$ of insulin solution $(1 \mathrm{mg} / \mathrm{ml}$ of $0.1 \mathrm{~mol} / 1 \mathrm{NaHCO}, \mathrm{pH} 9.7)$ and kept under continuous rotation to ensure permeation of the filter paper discs by the insulin for 20 hours at $4^{\circ} \mathrm{C}$.

The discs were then washed with $0.1 \mathrm{~mol} / 1$ $\mathrm{NaHCO}_{3}$ and treated with $1 \mathrm{~mol} / \mathrm{l}$ ethanolamine for three hours at room temperature. Then the paper discs were washed three times with $0.1 \mathrm{~mol} / \mathrm{l}$ borate buffer, $\mathrm{pH} 8.0$ and $0.1 \mathrm{~mol} / \mathrm{l}$ acetate buffer, $\mathrm{pH} 4.0$ and kept in $0.05 \mathrm{~mol} / 1$ phosphate buffer, $\mathrm{pH} 7.4$ containing $2 \mathrm{~g} / 1$ bovine albumin (Fraction V, Grade B, Calbiochem, La Jolla, California, USA) and $0.1 \mathrm{~g} / 1$ sodium azide at $4^{\circ} \mathrm{C}$.

One insulin-coupled paper disc was immersed in $0.1 \mathrm{ml}$ of patient's serum in a small plastic tube and the mixture was incubated for 3 hours at room temperature. After washing three times with $9 \mathrm{~g} / \mathrm{l}$ $\mathrm{NaCl}$ solution, the paper disc was immersed in $0.05 \mathrm{ml}$ of ${ }^{125} \mathrm{I}$-anti-IgE globulin solution (4.2 mCi $/ \mathrm{mg}, 0.16 \mu \mathrm{g} / \mathrm{ml}$, Pharmacia A. B., Uppsala, Sweden) and the mixture was incubated overnight at room temperature.

After washing three times with a portion of 

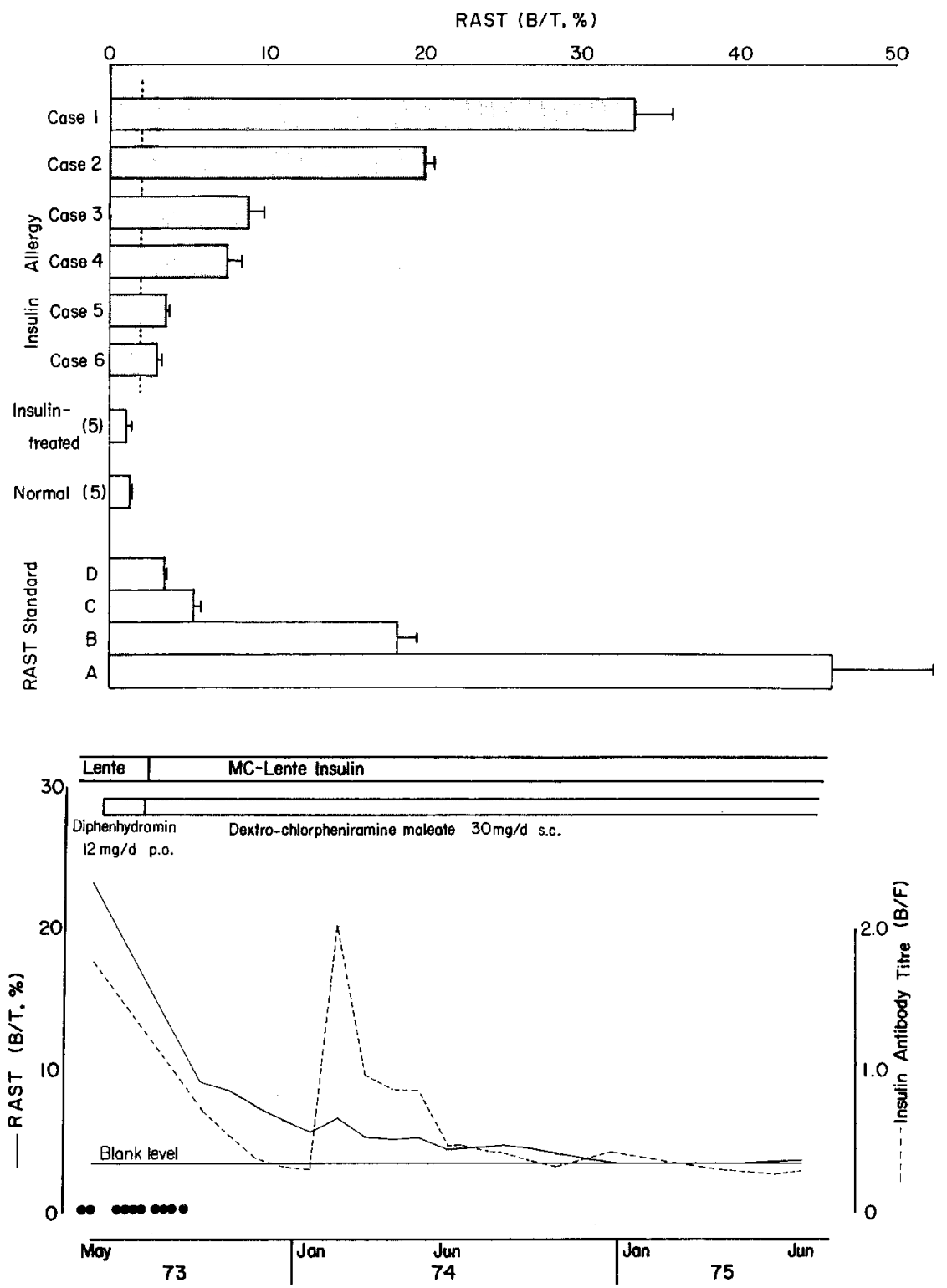

Fig. 1. RAST values of patients with insulin allergy, diabetics treated with insulin without allergy and normal subjects. Mean and standard deviation of triplicate determinations in allergic patients. The numbers in parentheses show the numbers of persons - results are mean \pm SD. A, B, C and $D$ of RAST show the values of the reference discs reacted with reference sera (A, B, C and D) of Phadebas RAST (Pharmacia). The dotted line means the upper limit of control (Mean +3 SD of insulintreated non-allergic diabetics and normal persons)

Fig. 2. Time course of serum RAST value, radioinsulin-binding titre and clinical symptoms in an allergic patient (Case 1, 35 year old, male) treated with highly-purified porcine insulin (Monocomponent insulin (Novo). An abrupt increase in insulin antibody titre was due to an erroneous use of conventional insulin for a week. The black circles mean occurrence of urticaria
$2.5 \mathrm{ml}$ of $9 \mathrm{~g} / \mathrm{l} \mathrm{NaCl}$ solution, the radioactivity of the disc was counted with a well type scintillation counter (Nihon-Musen Manufacturing Co., Tokyo, Japan). The RAST value was expressed as the percentage of the count of disc to the count of the added ${ }^{125} \mathrm{I}$-anti-IgE globulin solution $(\mathrm{B} / \mathrm{T})$.

The serum radioinsulin binding activity was measured by the polyethylene glycol method [5] with porcine ${ }^{125} \mathrm{I}$-insulin (Abbott Laboratories, Oak Ridge, Tenn., USA, $270 \mathrm{mCi} / \mathrm{mg}, 100 \mathrm{pg} / \mathrm{ml}$ of incubation medium) and expressed as the ratio of free to bound insulin in the presence of $0.1 \mathrm{ml}$ of serum in $1 \mathrm{ml}$ of incubation medium (normal range: less than 0.02).

The serum $\operatorname{IgE}$ was determined using the
Phadebas IgE Test (Pharmacia A.B., Uppsala, Sweden).

\section{Results}

The results of RAST with the disc coupled with purified bovine insulin are illustrated in Figure 1. No significant differences were observed between the RAST values of normal persons and insulintreated patients without insulin allergy. However, the RAST values of all patients with insulin allergy showed statistically significant higher values compared with the RAST values of normal persons and insulin-treated patients without insulin allergy. No 
Table 3. Effect of concentrations of serum and ${ }^{125} \mathrm{I}$-anti-IgE globulin on RAST values

\begin{tabular}{cccc}
\hline $\begin{array}{l}\text { Dilution } \\
\text { of serum }\end{array}$ & \multicolumn{3}{l}{ RAST, c.p.m. $(\mathrm{B} / \mathrm{T}, \%)^{\mathrm{a}}$} \\
\cline { 2 - 4 } & \multicolumn{2}{l}{ Concentration of ${ }^{125} \mathrm{I}$-anti-IgE globulin $(\mathrm{\mu g} / \mathrm{ml})$} \\
\cline { 2 - 4 } & 0.16 & 0.08 & 0.04 \\
\hline $2 \times$ & 4041 & 2428 & 1476 \\
$8 \times$ & $(4.1)$ & $(5.0)$ & $(6.0)$ \\
$32 \times$ & 1893 & 1088 & 763 \\
& $(1.9)$ & $(2.2)$ & $(3.1)$ \\
$128 \times$ & 687 & 571 & 307 \\
& $(0.7)$ & $(1.2)$ & $(1.3)$ \\
& 287 & 194 & 158 \\
& $(0.3)$ & $(0.4)$ & $(0.6)$
\end{tabular}

a Numbers out of parentheses show the radioactivity of disc (c.p.m.) and numbers in parentheses show the RAST value $(\mathrm{B} / \mathrm{T})$

correlation was observed between the RAST values and the severity of allergic symptoms or the size of area of inflammation in the skin test.

One patient with insulin allergy when taking a conventional insulin preparation was treated with a highly-purified insulin. He showed a gradual decrease of the RAST value and serum radioinsulinbinding activity (see Fig. 2).

The RAST values with the paper discs coupled with insulins of different species and purity are shown in Figure 3. A statistically significant difference between bonito and bovine insulin was observed in only one case.

The RAST values were similar with different lots of paper discs prepared under the same conditions. But when using out-dated ${ }^{125}$ I-anti-IgE globulin solution, slightly low RAST and high blank values were observed.

A RAST-positive serum was diluted serially with pooled normal serum. The RAST values of these mixtures using three different concentrations of ${ }^{125} \mathrm{I}$ anti-IgE globulin solution were determined. The RAST value fell with decrease in the concentration of the patient's serum at all three concentrations of ${ }^{125} \mathrm{I}$-anti-IgE globulin. The RAST value increased and the radioactivity of the disc decreased with decrease of the ${ }^{125}$ I-anti-IgE globulin concentrations (see Table 3.).

The inhibitory action of non-IgE antibody was assessed by measuring the RAST values of 1 ) a dilution of RAST-positive serum with RAST negative serum (both containing high titres of IgG antibodies) and 2) a dilution of RAST-positive serum with a normal pooled serum. The RAST values were slightly lower in the dilution of RAST-positive
Table 4. Inhibition of RAST by non-IgE antibody

\begin{tabular}{|c|c|c|c|c|}
\hline \multirow{3}{*}{$\begin{array}{l}\text { Dilution } \\
\text { of allergic } \\
\text { serum }\end{array}$} & \multicolumn{4}{|c|}{ Dilution of allergic serum ${ }^{a}$ with } \\
\hline & \multicolumn{2}{|c|}{ normal serum $^{\mathrm{b}}$} & \multicolumn{2}{|c|}{$\begin{array}{l}\text { serum from non-allergic } \\
\text { insulin-treated patients }\end{array}$} \\
\hline & $\operatorname{RAST}(\%)$ & $\begin{array}{l}\text { Antibody } \\
(\mathrm{B} / \mathrm{F})^{\mathrm{d}}\end{array}$ & $\operatorname{RAST}(\%)$ & $\begin{array}{l}\text { Antibody } \\
(\mathrm{B} / \mathrm{F})^{\mathrm{d}}\end{array}$ \\
\hline $1 \times$ & $14.7 \pm 0.8$ & 2.0 & $14.7 \pm 0.8$ & 2.0 \\
\hline $2 \times$ & $11.8 \pm 1.0$ & 1.2 & $9.5 \pm 0.3$ & 2.9 \\
\hline $4 \times$ & $7.9 \pm 1.0$ & 0.7 & $7.6 \pm 0.3$ & 3.2 \\
\hline $8 \times$ & $4.9 \pm 0.4$ & 0.4 & $4.8 \pm 0.1$ & 2.8 \\
\hline $16 \times$ & $4.5 \pm 0.4$ & 0.2 & $4.1 \pm 0.2$ & 2.3 \\
\hline Diluent & $1.4 \pm 0.1$ & 0.0 & $1.5 \pm 0.1$ & 2.2 \\
\hline
\end{tabular}

a Pooled serum from allergic patients

b Pooled serum from normal subjects

c Pooled serum from non-allergic insulin-treated patients

d Serum ${ }^{125}$ I-insulin binding activity

Cose 3
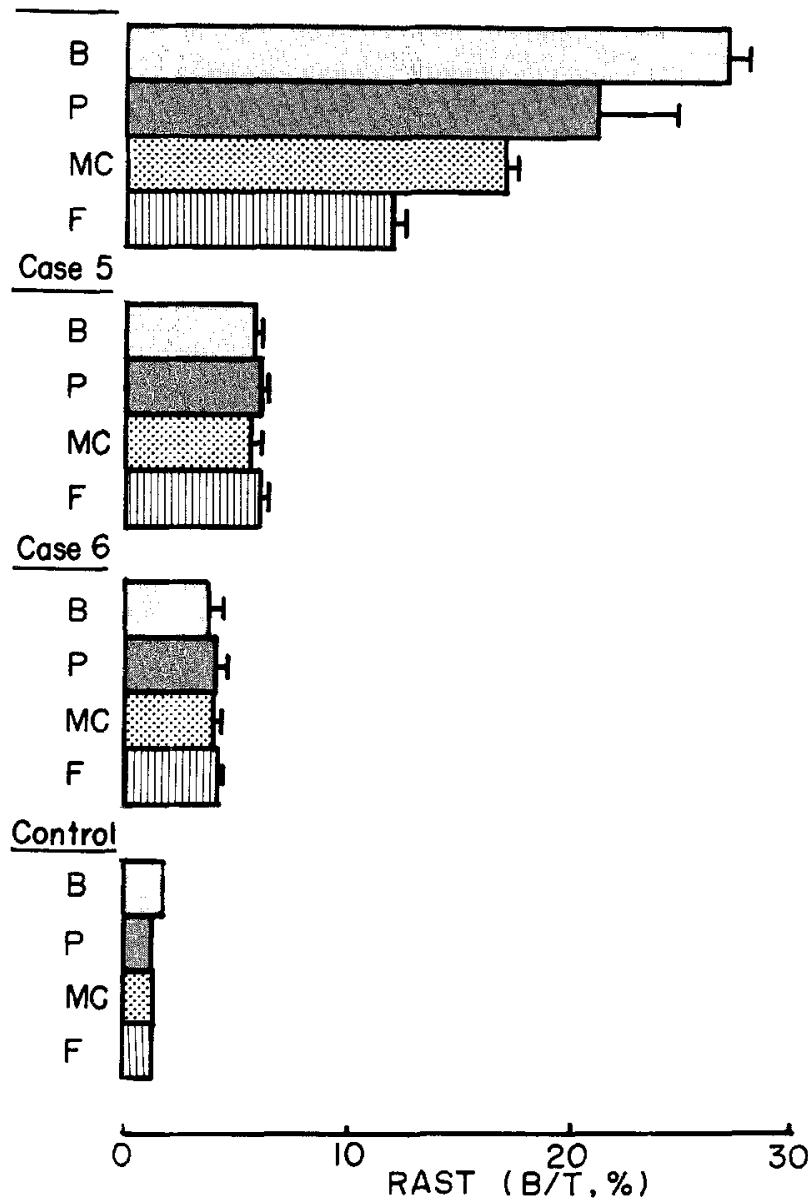

Fig. 3. RAST values with discs coupled with insulins from different sources. B: bovine insulin, P: porcine insulin, MC: highlypurified porcine insulin, F: bonito insulin (Mean and standard deviation of triplicate determinations) 
serum with RAST-negative serum containing IgG insulin antibodies as compared to the dilution of the RAST-positive serum with a normal pooled serum (see Table 4).

\section{Discussion}

The clinical usefulness of the RAST in the diagnosis of antigens in pollen allergy has been confirmed by many investigators $[6,7]$.

However, in order to use RAST for detecting IgE insulin antibody in serum of patients with insulin allergy a theoretical problem still existed. In contrast to pollen allergy, many patients with insulin allergy have high titres of non- $\operatorname{IgE}$ insulin antibody in their sera and the non-IgE insulin antibodies could competitively inhibit the first reaction of the RAST.

In pollen allergy, Yuninger and Gleich [8] reported an inhibitory action of non-IgE antibody on the RAST in a dilution test and Fujita et al. [9] confirmed the inhibitory action of non- $\operatorname{IgE}$ antibody using purified $\mathrm{IgE}$ and non- $\mathrm{IgE}$ antibodies.

In the RAST value of insulin, as described above, though a slight inhibition of the RAST by non- $\operatorname{IgE}$ antibody was observed in the range of high concentration of $\operatorname{IgE}$ antibody, little inhibition was observed in the range of low concentration of $\operatorname{IgE}$ antibodies. Therefore, from the practical point of view, there is no obstacle for detecting $\mathrm{IgE}$ antibodies from non-IgE antibody containing serum.

The facts that the RAST value was only slightly inhibited by the presence of non- $\operatorname{IgE}$ antibodies and the use of different species of insulin might be explained by a high capacity of the disc-coupled antigen in insulin RAST.

Though the presence of reagenic insulin antibodies in the patient's serum was directly confirmed by the Prausnitz-Küstner test only in two out of the six allergic patients, judging from their clinical symptoms and results of direct skin tests with purified insulin from several sources, their presence was probable in the four other patients. The fact that all of the allergic patients had significantly higher values showed the usefulness of the RAST as an in vitro assay method for detecting IgE insulin antibody. This is supported by the fact that an allergic patient showed a gradual decrease after treatment with highly-purified porcine insulin corresponding to amelioration of the clinical allergic symptoms.
In this study, skin tests and the RAST determination could not be performed immediately after the onset of symptoms, so the discrepancy between RAST value and size of reaction in skin test and severity of clinical symptoms might be due to this lag time. However, factors such as 1) fixation of reagenic antibody to mast cells, 2) release of chemical mediators and 3) actions of the chemical mediators on the tissue, may affect the dermal reactions. The individual differences of these factors could affect the severity of dermal reaction in addition to levels of $\operatorname{IgE}$ insulin antibody.

\section{References}

1. Patterson, R., Lucena, G., Metz, R., Robert, M.: Reagenic antibody against insulin: Demonstration of antigenic distribution between native and extracted insulin. J. Immunol. 103, 1061-1071 (1969)

2. Patterson, R., Millies, C. J., Robert, M.: Immunological reaction against insulin. II. IgE anti-insulin insulin allergy and combined IgE and IgG immunogenic insulin resistance. J. Immunol. 110, 1135-1145 (1973)

3. Wide, L., Bennich, E., Johansson, S. G. O.: Diagnosis of allergy by an in vitro test for allergic antibodies. Lancet 1967 II, $1105-1107$

4. Ceska, M., Eriksson, R., Varga, J. M.: Radioallergosorbent assay of allergens. J. Allergy Clin. Immunol. 49, 1-9 (1972)

5. Steinke, J.: A new screening test for circulating antibodies to insulin using polyethylene glycol. Diabetes 21, 379 (1972)

6. Aas, K., Johansson, S. G. O.: The radioallergosorbent test in the in vitro diagnosis of multiple reagenic allergy. A comparison of diagnostic approach. J. Allergy Clin. Immunol. 48, 134-142 (1971)

7. Berg, T., Bennich, H., Johansson, S. G. O.: In vitro diagnosis of atopic allergy. I. A comparison between provocation tests and the radioallergosorbent test. Int. Arch. Allergy Appl. Immunol. 40, 770 -778 (1971)

8. Yuninger, J.W., Gleich, G.J.: Seasonal changes in IgE antibodies and their relationship to IgG antibodies during immunotherapy for ragweed hay fever. J. Clin. Invest. 52, 1268-1275 (1973)

9. Fujita, Y., Wypych, J. I., Wicher, K.W., Reisman, R. E., Arbesman, C. E.: Inhibitory effect of nonreagenic antibody on RAST determination. J. Allergy Clin. Immunol. 53, 80-81 (1974)

Received: April 12, 1977, and in revised form: August 15, 1977

Shoichi Nakagawa, M. D.

The Second Department of Medicine

Hokkaido University School of Medicine

Kita-15, Nishi-7, Kita-Ku

Sapporo 060

Japan 